\title{
Environmental and Water Resources Management: Problems and Solutions
}

\author{
Robert Wenger $(\bowtie)^{1}$, Zhifeng Yang $(\bowtie)^{2}$ \\ 1 University of Wisconsin-Green Bay, Green Bay, WI 54311-7001, USA \\ 2 State Key Laboratory of Water Environment Simulation, School of Environment, Beijing Normal University, Beijing 100875, China
}

(C) Higher Education Press and Springer-Verlag Berlin Heidelberg 2011

Environmental problems and issues have no geographical bounds. Many are global in scale; others may be bounded in some manner to a particular region, yet share features with similar problems in other locales throughout the world. It is important, then, for environmental researchers, policymakers, and practitioners to reach across national and cultural boundaries to discuss these issues and learn from each other.

For more than 25 years an ongoing international seminar-study tour program initiated by the Environmental and Water Resources Institute (EWRI), a specialty institute within the American Society of Civil Engineers, has provided such a learning opportunity for engineers and scientists from throughout the world. Under the auspices of EWRI, seminar-study tours are scheduled approximately biennially at various locations around the world. Recent locations for seminar-study tour events have been Mexico (2006), Viet Nam (2008), Peru (2010), and China (2011). The Beijing seminar-study tour was held from October 26th to 31st and was hosted and co-sponsored by the School of Environment at Beijing Normal University. In addition to publicity support provided by EWRI, the Beijing seminarstudy tour received financial support from the University of Wisconsin-Green Bay, Green Bay, Wisconsin, USA, with the latter also serving as cosponsor.

The format for the Beijing seminar-study tour was a traditional one: Two days of seminar presentations and four days of field trips featuring visits to sites of cultural and technical interest. Approximately 25 presentations based on the theme, Environmental and Water Resources Management, were given during the two days. As a means of extending the capacity to learn and exchange ideas, seminar participants were invited to submit manuscripts for potential publication. Some chose to take advantage of this opportunity. The invitation for paper submissions was also extended to several persons who were not seminar participants. The results obtained from this paper solicitation are found in this special issue of Frontiers of Earth Science.

The 13 papers cover a rather wide range of topics, but all discuss water related issues in some form. The prevalence of papers that discuss topics related to water is a reflection both of the importance of these issues internationally and the expertise of the authors, most of whom are academicians or professionals in water-related fields.

Several of the papers address water related health issues. Specific topics include water quality deterioration in a network due to loss of disinfectant residuals because of the reaction between bulk phase disinfectants and pipe wall material (Clark, 2011), the need to rapidly detect contamination resulting from terrorist attacks (Deininger et al., 2011), and emergency response planning to reduce the impact of contaminated drinking water (Patterson and Adams, 2011).

Impacts of global climate change are discussed in several papers. Topics discussed in this general category are: A description of the effects of global climate change on the Arctic and the implications for hypothetical oil spills (Samuels et al., 2011) and tools and techniques that can be used to assess the impact of global climate change on urban drinking water and wastewater infrastructures (Clark et al., 2011).

In other papers, authors discuss impacts from a variety of potential disasters, including global climate change.

Received October 18, 2011

E-mail: wengerr@uwgb.edu, zfyang@bnu.edu.cn 
Here the topics are: the nature of water related disasters and metrics for evaluating impacts of disasters (Grayman, 2011) and spatial assessment methods for managing critical infrastructure networks under abnormal conditions (Möderl and Rauch, 2011). Two other papers consider the problem of protecting water and wastewater infrastructure from terrorist threats. The specific topics are: countermeasures water and wastewater utilities must adopt to prevent and minimize the damage in case of cyber attacks (Panguluri et al., 2011) and guidelines for enhancing security in water supply systems from intentional contamination risks (Di Cristo et al., 2011).

Various aspects of water and wastewater infrastructures are dealt with in many of the papers listed above. Other papers discuss infrastructure issues more directly. Younos (2011) advocates the use a holistic approach for planning and implementing water systems in urban environments. Clark and Thurnau (2011) describe a frailty model that can be used to evaluate the risk of failure in drinking water systems.

A coupling model that is useful for water quality simulation and assessment of river networks under tidal influences is discussed in a paper by Feng et al. (2011). They applied their model to the Suzhou River in China. A Monte Carlo simulation model for use in the economic evaluation of breakwater protection in harbors is described in a paper by Males and Melby (2011). Their model has been utilized by the US Army Corps of Engineers in a variety of coastal protection projects.

Obviously the many of the papers do not fit neatly into the categories as indicated above. Table 1 shows how the fifteen papers fall into overlapping categories.

In closing, we express our sincere appreciation to the many authors who have contributed papers to this special issue of Frontiers of Earth Science. In keeping with our global perspective, we note that the authors are from five different countries: Austria, China, Italy, Nigeria, and the United States.

Table 1 Categories for the fifteen papers

\begin{tabular}{|c|c|c|c|c|}
\hline Paper (authors' initials) & Human health & $\begin{array}{l}\text { Natural and human caused } \\
\text { disasters }\end{array}$ & Infrastructure & Other types of systems \\
\hline $\mathrm{C}$ & $x$ & & $x$ & \\
\hline $\mathrm{CT}$ & & & $x$ & \\
\hline PA & $x$ & $x$ & & \\
\hline CLB & & $x$ & $x$ & \\
\hline SAC & & $x$ & & \\
\hline PPC & & $x$ & $x$ & \\
\hline MM & & & & $x$ \\
\hline MR & & $x$ & $x$ & \\
\hline FWC & & & & $x$ \\
\hline G & & $x$ & & \\
\hline DLC & $x$ & $x$ & & \\
\hline DLD & & $x$ & $x$ & \\
\hline Y & & & $x$ & \\
\hline
\end{tabular}

\section{References}

Clark R M (2011). Chlorine fate and transport in drinking water distribution systems: Results from experimental and modeling studies. Frontiers of Earth Science, doi: 10.1007/s11707-011-0194-x

Clark R M, Li Z W, Buchberger S G (2011). Adapting water treatment design and operations to the impacts of global climate change. Frontiers of Earth Science, doi: 10.1007/s11707-011-0197-7

Clark R M, Thurnau R C (2011). Evaluating the risk of water distribution system failure: A shared frailty model. Frontiers of Earth Science, doi: 10.1007/s11707-011-0195-9

Di Cristo C, Leopardi A, de Marinis G (2011). Water infrastructure protection against intentional attacks: An experience in Italy. Frontiers of Earth Science, doi: 10.1007/s11707-011-0208-8

Deininger R A, Lee J Y, Clark R M (2011). Rapid detection of bacteria in drinking water and water contamination case studies. Frontiers of Earth Science, doi: 10.1007/s11707-011-0206-X

Feng L, Wang D G, Chen B (2011). Water quality modelling for a tidal river network: A case study of the Suzhou River. Frontiers of Earth Science, 
doi: $10.1007 / \mathrm{s} 11707-011-0204-\mathrm{Z}$

Grayman W M (2011). Water-related disasters: A review and commentary. Frontiers of Earth Science, doi: 10.1007/s11707-011-0205-y

Males R M, Melby J A (2011). Monte Carlo simulation model for economic evaluation of rubble mound breakwater protection in harbors. Frontiers of Earth Science, doi: 10.1007/s11707-011-0200-3

Möderl M, Rauch W (2011). Spatial risk assessment for critical network infrastructure using sensitivity analysis. Frontiers of Earth Science, doi: 10.1007/s11707-011-0202-1

Panguluri S, Phillips W, Cusimano J (2011). Protecting water and wastewater infrastructure from cyber attacks. Frontiers of Earth Science, doi: 10.1007/s11707-011-0199-5

Patterson C L, Adams J Q (2011). Emergency response planning to reduce the impact of contaminated drinking water during natural disasters. Frontiers of Earth Science, doi: 10.1007/s11707-011-0196-8

Samuels W E, Amstutz D E, Crowley H A (2011). Arctic climate change and oil spill risk analysis. Frontiers of Earth Science, doi: 10.1007/s11707011-0198-6

Younos T (2011). Paradigm shift: Holistic approach for water management in urban environments. Frontiers of Earth Science, doi: 10.1007/s11707011-0209-7 